\title{
Articles
}

\section{International Business Encounters Organized Crime: The Case of Trafficking in Human Beings}

\author{
By Maria O’Neill*
}

\begin{abstract}
With increasing globalization, transnational crime in general, and human trafficking in particular, a design of new legal framework is required in order to effectively operationalize interstate law enforcement operations and prosecutions. The development of a transnational criminal legal framework-or frameworks-can build on pre-existing transnational economic frameworks. There is also the need to extend the application of domestic law beyond national borders to influence transnational corporate behavior. Regulations based on reflexive law are one possible approach. Teubner's idea of reflexive law has been informing developments in this area. This approach uses traditional national law to inform corporate governance strategies in order to achieve effects on the market. A few jurisdictions have already adopted measures modeled on this approach to tackle human trafficking and slavery-like conditions in global supply chains. Weaknesses in the approaches adopted by the UK and the State of California have already been identified. If strengthened, this approach could be adopted in more jurisdictions-including the EU-and also to combat more areas of transnational crime-such as money laundering. This paper will examine the resulting challenges using human trafficking as a case study.
\end{abstract}

* Senior Lecturer in Law, University of Abertay. 


\section{A. Introduction}

Trafficking of Human Beings (THB) is a core business of international criminal organizations. It is seen as a relatively low-risk/high-reward crime. At a global level, human trafficking is prohibited by the Protocol to Prevent, Suppress and Punish Trafficking in Persons, Especially Women and Children, supplementing the United Nations Convention against Transnational Organized Crime published in 2000, ${ }^{1}$ and more recently by EU Directive $2011 / 36 / E U,{ }^{2}$ for the EU member states. THB does not involve "voluntary" prostitution-as understood by the law enforcement community-and can arise in circumstances similar to, but as a crime, is separate from traditional slavery, human smuggling, or poor working conditions. It builds on pre-existing and pre-defined crimes of slavery, servitude, forced labor, and compulsory labor. In the context of this paper it also involves the production of products-more so goods, rather than services-for global supply chains using harsh and degrading working conditions-including bonded labor. Transnational corporations are responsible for the procurement, manufacturing, and delivery of a very large percentage of the commodities in our domestic markets. While national laws address criminal law and labor conditions within our own jurisdictions, they have little effect in governing behavior outside their relevant jurisdiction.

With increasing globalization, the issue of "the application of domestic law to international actors" arises. ${ }^{3}$ In the case of both transnational criminal law and transnational commercial law "the power of command-and-control regulation largely stops at the border." 4 The international business world bisects the world of cross border criminal law in a number of key areas. This paper will examine the resulting theoretical challenges using human trafficking as a case study. Two key points of intersection between the commercial and criminal world are: Human trafficking-and related slavery conditions-in global supply chains, now addressed in a number of jurisdictions, including the UK; and combating the laundering of proceeds of human trafficking, which is currently a global effort. The focus of this paper will be on the efforts of EU states to combat these two issues, and the need for EU measures to have extraterritorial effect, given the nature of global supply chains. Measures to combat money laundering through the financial and banking sector generally are more developed than the more recently recognized phenomenon of human trafficking

1 See Protocol to Prevent, Suppress and Punish Trafficking in Persons, Especially Women and Children, Supplementing the United Nations Convention Against Transnational Organized Crime, opened for signature Nov. 15, 2000, 2225 U.N.T.S. 209.

${ }^{2}$ See Directive 2011/36, of the European Parliament and of the Council of 5 April 2011 on Preventing and Combating Trafficking in Human Beings and Protecting its Victims, and Replacing Council Framework Decision 2002/629/JHA, 2011 O.J. (L 101) 1 (EU) [hereinafter Council Directive 2011/36].

${ }^{3}$ Bradley Girard, Corporate Transparency Through the SEC as an Antidote to Substandard Working Conditions in the Global Supply Chain, 21 GEO. J. ON POVERTY L. \& PoL'Y 317, 321 (2014).

${ }^{4}$ Id. at 322 . 
in global supply chains. While measures taken to combat money laundering could be further developed, those measures already taken to date are likely to inform how human trafficking and slavery like conditions can be tackled in global supply chains.

Reflexive law is an attempt by jurisdictions to make transnational businesses link to those jurisdictions in order to structure and manage their transnational businesses in a way that complies with the laws and norms of the legislating jurisdiction. The design of UK law in its response to its requirement to implement Directive 2011/36/EU, ${ }^{5}$ reflecting the idea of Teubner's reflexive law, to address both human trafficking in global supply chains, allied to a similar response being adopted by anti-money laundering regimes, would together provide additional mechanisms, if adopted more widely, -working with the global business and banking communities, - to combat this form of organized crime. Reflexive law shows promise, particularly in extending the reach of the command and control state into the areas where the transnational criminal world bisects the transnational commercial and banking world. Reflexive law has been adopted in a number of measures, which will be discussed below. Concrete evidence of reflexive law's effectiveness still needs to be measured, and it is arguable that those measures already adopted will need to be made more robust in order to ensure that effectiveness. This paper will critically analyze the potential for adopting and further developing reflexive law mechanisms to combat the transnational crime of human trafficking, and its connection to anti-money laundering issues.

Human trafficking-while it can occur within one state-is more often encountered across a number of jurisdictions, these being countries of origin, transit, and destination. The same can be said about corporate global supply chains. An individual jurisdiction's laws, or those of the EU, will not address-either directly or indirectly-behaviors or crimes that occur in third states. There is a need to develop extraterritorial effect for state or EU laws. As stated by Girard, "the power of command-and-control regulation largely stops at the border." ${ }^{6}$ Corporations, or financial systems which are based, or operate, in European or EU jurisdictions, are required to meet the laws of the jurisdictions in which they are based or operate. Reflexive law is an imperfect tool, but it is currently being adopted by both the UK and the EU in order to gain some extraterritorial effect for their internal standards and laws-particularly where transnational crime concerns bisect the realm of private commercial operators.

This paper will start with an examination of reflexive law, building on Teubner's original concept. It will then go on to examine the relevance of reflexive law to the challenges of human trafficking in global supply chains. Three pieces of legislation from three different jurisdictions, the EU, the US State of California, and the UK are examined here. The EU's

\footnotetext{
${ }^{5}$ See Modern Slavery Act 2015, c. 30, § 54 (Eng.).

${ }^{6}$ Girard, supra note 3, at 322.
} 
Directive 2014/95/EU on the disclosure of non-financial and diversity information ${ }^{7}$ comes close to but does not expressly cover the issue of human trafficking in global supply chains. Its approach-modeled on reflexive law-is very similar to those adopted by the UK in Section 54 of the Modern Slavery Act 2015. The UK's approach to human trafficking in global supply chains has also been heavily influenced by the State of California's Transparency in the Supply Chains Act of 2010, ${ }^{8}$ with California having been a first mover on this issue. Much can be learned, not only from earlier adopters of provisions modeled on reflexive law in global supply chains, but also from evaluation of the adoption of laws modeled on reflexive law in other areas of practice such as social and environmental law. With some jurisdictions having adopted a reflexive law approach to tackling human trafficking and slavery in global supply chains-and the possibility of this approach being adopted in further jurisdictionsthere is then the issue of making the reflexive law approach to regulation actually work. This issue is examined later on in the article and is followed by an examination of trafficking as a test case for reflexive law.

\section{B. Reflexive Law}

Teubner's concept of reflexive law is a development of earlier responsive law theories. It relies on the "fusion of public and private governance regimes." ${ }^{9}$ The underlying premise is that law is supposed to "provide congruent generalizations of the expectations for the whole of society." ${ }^{10}$ In addition to the traditional "vertical' subordination of citizens to their sovereigns," there is a need for "horizontal' relations between equally situated market actors" ${ }^{11}$ in public-private governance regimes. These horizontal relations become relevant in the context of globalization.

Reflexive law recognizes "the limits of regulatory law"12-limits, which we recognize in the context of globalization. Reflexive law originates "from a social theoretical perspective

\footnotetext{
${ }^{7}$ See Directive 2014/95, of the European Parliament and of the Council of 22 October 2014 Amending Directive 2013/34/EU as Regards Disclosure of Non-financial and Diversity Information by Certain Large Undertakings and Groups, 2014 O.J. (L 330) 1 (EU) [hereinafter Council Directive 2014/95].

${ }^{8}$ See Transparency in the Supply Chains Act, CAL. CIV. CODE $§ 1743.43$ (2012) [hereinafter Californian Act].

${ }^{9}$ Agnieszka Janczuk-Gorywoda, Public-Private Hybrid Governance for Electronic Payments in the European Union, 13 GERMAN L.J. 1438, 1439 (2012).

${ }^{10}$ Gunther Teubner, Substantive and Reflexive Elements in Modern Law, 17 L. \& Soc'Y REV. 239, 273 (1983).

${ }^{11}$ Daniela Caruso, Private Law and State-Making in the Age of Globalization, 39 N.Y.U. J. INT'L L. \& POL 2, 3 (2002).

12 Olivier De Schutter \& Simon Deakin, Reflexive Governance and the Dilemmas of Social Regulation, General Introduction, in SOCIAL RIGHTS AND MARKET ForCES; IS THE OPEN COORDINATION OF EMPLOYMENT AND SOCIAL POLICIES THE FUtURE OF SOCIAL EUROPE?, 7 (Olivier De Schutter \& Simon Deakin eds., 2005).
} 
rather than a strictly legal one," ${ }^{13}$ recognizing the "complexity of social life and the diversity of the many institutions created to achieve various ends," and aims "to guide rather than to suppress" that complexity. ${ }^{14}$ Given the levels of complexity that are to be regulated by reflexive law, legislators need to constantly reflect on its effect and adjust accordingly: Having created a "disclosure based system" traditional enforcement is then reserved as a back-up to that system. ${ }^{15}$

In designing "horizontal" relations, which can extend outside the territorial boundary of the state, reflexive law "seeks to design self-regulating social systems through norms of organization and procedure." 16 In this way "semi-autonomous social systems" are not only reshaped, but so also are their "methods of coordination with other social systems." ${ }^{17}$ This type of law therefore is "characterized by particularism, result-orientation, an instrumentalist social policy approach, and the increasing legalization of formerly autonomous social processes." ${ }^{18}$ As Teubner has said, "reflexive rationality in law obeys a logic of procedural legitimation," ${ }^{19}$ thereby having "institutional legal characteristics quite different from its substantive counterpart." 20

The drive to develop the concept of reflexive law arose from the understanding that "judicial control and state regulation of associated behavior seem to [have reached] the limits of their control capacity." ${ }^{21}$ This is particularly true in the context of globalization-in both transnational economic law and effectively addressing transnational security-and law enforcement threats. The strategy is to have large, multi-national companies and global supply chains "substitute for outside interventionist control," something which is highly problematic in the transnational sphere, for the development of "effective internal control structure[s]." 22 This would be regulated when the large multi-national company-or key parts of the global supply chain-bisect one or more key state jurisdictions, those jurisdictions being sites of reflexive law regulation. As stated by Shaffer, "in a globalized

\footnotetext{
${ }^{13}$ Eric W. Orts, A Reflexive Model of Environmental Regulation, 5 Bus. EtHICs Q.779, 780 (1995).

${ }^{14}$ Id. at 780 .

${ }^{15} / d$. at 787 .

${ }^{16}$ Teubner, supra note 10 , at $254-55$.

${ }^{17}$ Id. at 255 .

${ }^{18} / d$. at 267.

${ }^{19} / d$. at 270.

${ }^{20} / d$. at 256.

${ }^{21} / d$. at 278.

${ }^{22} / d$.
} 
world, much of law is subject to transnational influences and pressures, but more powerful states are the primary exporters of legal norms." ${ }^{23}$ The larger economies of the US, the EU, and the UK would be key players in influencing global commercial entities. In this way mostif not all-of the large multi-national companies or global supply chains would become subject to the provisions of reflexive law regulation, thereby either facilitating better transnational commercial effectiveness-something that is of direct interest to the commercial world-while effectively contributing to the minimization of global security and law enforcement threats. This should also be of interest to responsible business.

Therefore-as stated by Teubner-“law's role is to decide about decisions, regulate regulations, and establish structural premises for future decisions, in terms of organization, procedure and competencies." ${ }^{24}$ Law's role in one subsystem should have specific outcomes in other related or parallel subsystems. Law therefore "attempts to balance bargaining power, but this only indirectly controls specific results," 25 and has been shown by different researchers to have had variable success in different areas of business and law. ${ }^{26}$ of relevance to this point is who has or should have the necessary bargaining power. The effectiveness of reflexive law measures also need to be subjected to "strong empirical testing" before they can be claimed to be truly effective. As Teubner himself points out, "the 'fallacy of misplaced concreteness' is almost inevitable." ${ }^{27}$

\section{The Relevance of Reflexive Law to Human Trafficking in Global Supply Chains}

Globalization is not just affecting the economic sphere of activities. As is becoming obvious to more and more people in their ordinary lives, globalization is also bringing with it new security threats. There is a need to develop a transnational criminal law framework to address issues that range from worldwide cyber threats to international terrorism movements. One particular crime that needs a transnational approach is THB, which was one of the earliest crimes that the EU addressed, in $1997 .{ }^{28}$ The vast majority of THB cases are connected with organized crime, as by the nature of movement, control, and exploitation of individuals requires a number of people to be involved. This is evidenced by the fact that the UN Protocol to Prevent, Suppress and Punish Trafficking in Persons,

\footnotetext{
${ }^{23}$ Gregory Shaffer, Transnational Legal Process and State Change, 37 L. \& Soc. INQUIRY 229, 231 (2011).

${ }^{24}$ Teubner, supra note 10, at 275.

${ }^{25} / d$. at 276.

${ }^{26} / d$.

${ }^{27}$ Id.

${ }^{28}$ See Joint Action 97/154, of 24 February 1997 Adopted by the Council on the Basis of Article K.3 of the Treaty on European Union Concerning Action to Combat Trafficking in Human Beings and Sexual Exploitation of Children, 1997 O.J. (L 63) 2 (EU).
} 
Especially Women and Children is attached to the UN Convention on Transnational Organized Crime 2000. The predominant motivational factor for THB is money. This poses a challenge for both law enforcement and financial services generally. The challenges arising from the crime of THB are multifaceted. An area for development-and the focus of this paper-could be on those issues which are of relevance to law enforcement, but are more closely related to the commercial world. This paper addresses the potential for development of this transnational commercial-crime nexus, using one of the tools used by transnational economic law to date, reflexive law.

The line of reasoning that reflects the idea of reflexive law has recently been adopted to address the issue of THB in global supply chains. In an effort to address the behavior of business operating global supply chains-and reflecting the limitations of the command and control approach of domestic jurisdictions-a new way of conceptualizing law needs to be developed. Both international trade and transnational crime bridge jurisdictions. There is a need to develop legal frameworks which occupy the space between national jurisdictions, and which addresses issues which arise when there are gaps or weaknesses in one of the interconnected jurisdictions relevant to both criminal and commercial global supply chains. One way would be to develop inter-jurisdictional legal frameworks under the umbrella of the UN Convention on Transnational Crime 2000. Another is to develop the extraterritorial effect of domestic jurisdictions. One of the tools being used by domestic jurisdictions is to enact provisions to require international business-with a substantial connection with that jurisdiction - to manage their businesses in ways which meet the laws and norms of that particular jurisdiction. These are therefore laws which require internal corporate processes to be implemented as part of the company's corporate governance framework.

While provisions based on reflexive law have yet to be adopted by the EU to directly address THB-or security provisions in general-the approach is not unknown to the EU. The reflexive law approach has already been adopted within the EU legal framework, and it is the argument of this paper that the EU would benefit from provisions similar to those adopted by the US State of California, or those in the UK, to combat trafficking in human beings in global supply chains. Similar provisions have already been written into the EU legal framework through Directive 2014/95/EU of the European Parliament and of the Council of 22 October 2014 amending Directive 2013/34/EU as regards to disclosure of non-financial and diversity information by certain large undertakings and groups. ${ }^{29}$ Directive 2014/95/EU applies to "[l]arge undertakings which are public-interest entities exceeding on their balance sheet dates the criterion of the average number of 500 employees during the financial

\footnotetext{
${ }^{29}$ See Directive 2013/34, of the European Parliament and of the Council of 26 June 2013 on the Annual Financial Statements, Consolidated Financial Statements and Related Reports of Certain Types of Undertakings, Amending Directive 2006/43/EC of the European Parliament and of the Council and repealing Council Directives 78/660/EEC and 83/349/EEC, 2013 O.J. (L 182) 19 (EU) [hereinafter Council Directive 2013/34].
} 
year." 30 Directive 2013/34/EU ${ }^{31}$ defines public-interest entities as "companies governed by the laws of a member state," and are so designated by member states as having "significant public relevance because of the nature of their business, their size or the number of their employees." 32 The obligation is to make a non-financial statement. This statement needs to cover "the extent necessary for an understanding of the undertaking's development, performance, position and impact of its activity, relating to as a minimum environmental, social and employee matters, respect for human rights, anti-corruption and bribery matters." 33

Packaged as part of corporate social responsibility, rather than as an effort to combat-inter alia-human trafficking, this EU provision was enacted in order to facilitate the "disclosure of non-financial information" in order to assist in "the measuring, monitoring and managing of undertakings' performance and their impact on society," ${ }^{34}$ with an eye specifically on social, to include corruption, and environmental issues. The intention behind the reporting mechanism - and its audit - is to require businesses to seriously take into consideration set EU and national environmental and social objectives. In giving proper consideration to these objectives, businesses are expected to modify their decision-making processes, thereby reorienting the entirety of their operations in order that the business aims to achieve outcomes which are more in line with objectives set in other EU laws and policy documents. The resulting fusion of public law - the directive-with an anticipated refocusing of internal corporate governance strategies, should lead to a change of behavior of a large number of the dominant players on the market. This should then have a knock-on effect of changing the market as a whole, with many larger companies requiring their suppliers to operate to the same high standards, in order to maintain transnational supply chain integrity.

Directive 2014/95/EU was to be implemented in EU member states by December 06, 2016, with a view to applying to financial years either starting on January 01,2017 , or during the 2017 calendar year, depending on business practice in the EU. The effectiveness of these provisions modeled on reflexive law therefore still have to be evaluated. A weakness in this provision-in the context of this paper-is that it does not expressly address the issue of THB, something which has been addressed in other jurisdictions, initially in the US State of California, and more recently in the UK. In addition, there is no corresponding provision elsewhere in the EU Area of Freedom Security and Justice legal framework. Little amendment would be required of Directive 2014/95/EU in order to address the issue of THB.

\footnotetext{
${ }^{30}$ Council Directive 2014/95, supra note 7, at art. 1.

${ }^{31}$ Council Directive 2013/34, supra note 29.

${ }^{32} / d$. at art. 2.

${ }^{33}$ Council Directive 2014/95, supra note 7, at art.1 (inserting a new art. 19(a) to Directive 2013/34).

${ }^{34}$ Id. at para. 3.
} 
Nevertheless, any such amendment might be informed by the drafting of both the Californian and UK provisions, and post-enactment evaluation of effectiveness. In addition, a reflexive law approach to tackling money laundering within the EU legal framework would also be useful. The EU's approach to legislative drafting in Directive 2014/95/EU already has some similarity with the UK provision on human trafficking in global supply chains, as pointed out in the UK Home Office guide to Transparency in Supply Chains. ${ }^{35}$

The lead jurisdiction on tackling human trafficking in global supply chains is the US State of California. There, the crime of human trafficking at the US federal level is addressed by the Victims of Trafficking and Violence Protection Act of 2000, as amended, which, inter alia, amended the U.S. Code to cover this crime. ${ }^{36}$ This is supplemented by the State of California through the Transparency in Supply Chains Act 2010-the Californian Act-which came into effect in 2012. ${ }^{37}$ The Californian Act required every retail seller and manufacturer doing business in this state-as defined by Californian tax law-and with annual worldwide gross receipts exceeding US $\$ 100$ million to meet certain disclosure requirements. ${ }^{38}$ These disclosure requirements are for the purposes of informing, at a minimum, other businesses, the authorities, and consumers the extent that the "retail seller or manufacturer" verifies the integrity of its supply chain to be free from human trafficking and slavery, and conducts audits of suppliers, with the requirement to state if the "verification was not an independent, unannounced audit." ${ }^{39}$ In addition, all materials from suppliers incorporated into their own products must be similarly certified. ${ }^{40}$ Further, internal corporate governance structures must include "internal accountability standards and procedures for employees or contractors failing to meet company standards regarding slavery and trafficking." ${ }^{\prime 1}$ In addition, employees, and management responsible for ensuring that supply chains do not include products of human trafficking or slavery, must be given appropriate training. ${ }^{42}$

The focus of the Californian Act is on disclosure and informing the consumer and other interested parties. The intention is that greater transparency will lead to peer and public pressure to adjust behavior. There is no requirement in the Californian Act to actually adjust

\footnotetext{
${ }^{35}$ See Home Office, Transparency in Supply Chains: A Practical Guide, 2015, at 26 (Eng.).

${ }^{36}$ See generally 22 U.S.C. § 7101 (2018), e.g. inserting, inter alia, new arts. 1589-1591.

37 Organization for Security and Co-operation in Europe, LeVeraging Anti-Money laundering Regimes to Combat TRAFFICKING IN HUMAN BEINGS 26 (2014).

${ }^{38}$ Californian Act at $\S 3$.

${ }^{39} / d$. at $\S \S 3(a)(1) \& 2$.

${ }^{40}$ See id. at $\S 3(3)$.

${ }^{41} / d$. at $\S 3(\mathrm{a})(4)$.

${ }^{42}$ See id. at $\S 3(a)(5)$.
} 
corporate behavior to ensure that the supply chain is actually free of products produced by human trafficking or slavery victims. Nonetheless, the reflexive law element would arise for companies which do wish to comply with the higher standards and want to be seen to be delivering human trafficking and slavery free products to the market. At the time of the enactment of the Californian Act it was "expected to apply to approximately 3,200 global companies." 43 It introduced novel features, which have been built on by the UK in its Modern Slavery Act 2015.

While the Modern Slavery Act 2015 is primarily focused on the jurisdiction of England and Wales, its transparency in supply chains provisions, ${ }^{44}$ with regard to slavery and human trafficking, applies to the whole of the UK. Whether the UK global supply chains provisions are or will be effective in achieving their stated objectives is a matter that requires further examination. Section 54 applies to commercial organizations which supply goods or services and have a total turnover ${ }^{45}$ as specified by regulation made by the Secretary of State, currently at STG $£ 36$ million. ${ }^{46}$

Neither the above-mentioned UK, nor the EU initiatives in the area of human rights reporting by businesses operate in a vacuum, with both the $\mathrm{UN}^{47}$ and the Organization for Economic Cooperation and Development $(\mathrm{OECD})^{48}$ having similar provisions in their relevant policy documents. Human trafficking is addressed by three different pieces of legislation in the UK, reflecting the fact that this issue is predominantly a matter for the devolved governments in both Scotland and Northern Ireland. The England and Wales legislation - the Modern Slavery Act $2015^{49}$ - provides for two distinct crimes: Section 1 offense of "slavery, servitude and forced or compulsory labour," which arguably in itself could be viewed as four different but overlapping crimes, and the Section 2 offense of "human trafficking." The Scottish and Northern Irish legislations ${ }^{50}$ take a similar approach. The breadth of definitions used would

${ }^{43}$ Jonathan Todres, The Private Sector's Pivotal Role in Combating Human Trafficking, 3 CAL. L. REV. CIR. 80, 81 (2012).

${ }^{44}$ Modern Slavery Act 2015, $\S 54$ (which came into force on October 29, 2015, pursuant to the Modern Slavery Act 2015 (Commencement No. 3 and Transitional Provision) Regulations 2015, SI 2015/1816 (Eng.)).

${ }^{45}$ See Modern Slavery Act 2015 at § 54(3).

${ }^{46}$ Modern Slavery Act 2015 (Transparency in Supply Chains) Regulations 2015, SI 2015/1833, § 2 (Eng.).

${ }^{47}$ See UN Office of the High Commissioner for Human Rights, Guiding Principles on Business and Human Rights Implementing the United Nations "Protect, Respect and Remedy" Framework (2011).

${ }^{48}$ See Organisation for ECONOMic Co-operation and DeVelopment, OECD GUidelines for Multinational Enterprises RESPONSIBLE BUSINESS CONDUCT MATTERS (2014).

${ }^{49}$ A number of provisions of the Modern Slavery Act 2015 apply to the whole of the UK, to include the Section 54 provision on human trafficking in global supply chains. See Modern Slavery Act 2015 at $\S 54$.

${ }^{50}$ See generally Human Trafficking and Exploitation (Scotland) Act 2015, (ASP 12); see also The Human Trafficking and Exploitation (Criminal Justice and Support for Victims) Act (Northern Ireland) 2015 c. 2. 
cover abusive situations that would not fall within the definitions of human trafficking used in UN, Council of Europe, or EU texts. This difference in approach may have an effect on addressing this type of exploitation in an otherwise legitimate businesses global supply chain.

Another point where ostensibly legitimate business bisects THB, is in the context of money laundering of criminal proceeds. At least some of the funds associated with THB are being handled by reputable financial and business entities in Western Europe. ${ }^{51}$ Financial institutions and money transfer services have been key in all THB case studies published to date in "moving the proceeds and instrumentalities of THB." The Organization for Security Cooperation in Europe (OSCE) has advocated the full leverage of "the private sector's access to the financial transactions of criminals," in order for countries to be more effective in tackling this crime. ${ }^{52}$ There is, therefore, scope for the further development of reflexive law mechanisms in this area.

There have been, at least to date, a very low number of Suspicious Activity Reports (SARs) identifying either human trafficking or its related crime, human smuggling. ${ }^{53}$ As the OSCE has stated, while THB is "in many respects a unique crime," its associated money laundering processes are "identical to those used for other types of crime." ${ }^{54}$ This has been echoed in the Financial Action Task Force (FATF) report on the topic, ${ }^{55}$ which points out that "there is no specific guidance on money laundering associated with THB[/ smuggling of migrants]," as "the instruments and the sectors implied are the same as for other criminal activities." The OSCE has pointed out that THB related financial transactions have often been carried out through money or value transfer services-in particular money transmitters and cash couriers-which face little supervision and monitoring in most countries. ${ }^{56}$ For example, Guzman, reporting on a US/Canadian case, pointed out the use of prepaid cards to move funds across borders. ${ }^{57}$ The traditional banking system has also been used effectively to move traffickers' monies. Harnessing the financial-and related sectors-abilities and

\footnotetext{
${ }^{51}$ LeVERAgIng ANTI-MONey LAUNDERING RegIMES, supra note 37, at 14.

${ }^{52}$ Id. at 9.

53 Susan Grossey, I am not a number, I am a free man, Money LAUNDERING BULletin 15 (Sept. 2011), http://www.airant.it/system/files/MLB\%20Sept\%202011.pdf.

${ }^{54}$ LeVeraging ANTI-Money LaUndering Regimes, supra note 37 , at 9.

${ }^{55}$ Financial Action Task Force, Money Laundering Risks Arising from Trafficking in Human Beings and Smuggling of MIGRANTS 63 (2011).

${ }^{56}$ LeVeraging ANTI-Money LaUndering Regimes, supra note 37 , at 18.

${ }^{57}$ See Daniela Guzman, How Financial Institutions Lead Way in Battle Against Human Trafficking, INSIGHT CRIME, (May 6, 2014), https://www.insightcrime.org/news/analysis/how-financial-institutions-lead-way-in-battle-againsthuman-trafficking/.
} 
knowledge of their own business's practices to combat transnational THB would be a step forward.

Reliance is often made on private or commercial actors for security related services, as will be required in the development of reflexive law for transnational law enforcement or security purposes. Reflexive law attempts to address the "application of domestic law to international actors." ${ }^{58}$ The approach of reflexive regulation is to set the required objective by way of law-which is mandatory on the legal entities operating within a particular jurisdiction-but leaving to the market operators to "determine the most efficient and effective ways to achieve [the] desired results." ${ }^{59}$

Regulating through reflexive law, therefore, can lead to many forms of state adjustment. For example, the shift of responsibility from the state to, in the commercial world, the market, will in some cases "create ... new public-private hybrid models of governance." ${ }^{60}$ While the security and law enforcement world will be less interested in the state ceding power to the market, nevertheless new - or at least additional-modes of governance will be required in order to effectively tackle transnational threats. In the absence of a global regulatory framework in this area, a number of new strategies will have to be developed. While the state will increasingly be moving from rowing to steering, the combination of "territorially focused as well as deterritorialized normative structures" will be leading to "increasingly complex forms of steering mechanisms." ${ }^{\prime 1}$ In addition, there may be a need to engage in a paradigmatic shift from the traditional state-centered top-down approach of legislative drafting, and to adopt an approach to regulation, which also allows the development of a bottom-up system. In this way it should be possible to develop "regulatory mechanisms [created using the] cooperative efforts [of] various kinds of actors below the state level," 62 and which operate in the global economic community. In approaching this issue there is a need to recognize that transnational economic law-as it has developed to date-has been recognized to induce "legal change [and] can have broader systemic effects within states" while "reconfiguring the respective roles of the state, the market, and other forms of social ordering." 63

\section{Making the Reflexive Law Approach Work}

\footnotetext{
${ }^{58}$ Girard, supra note 3, at 321.

${ }^{59} / d$. at 338.

${ }^{60}$ Shaffer, supra note 23 , at 244.

${ }^{61}$ Christian Tietje et Al., Philip C. Jessup's Transnational Law ReVisited 28 (Christian Tietje et al. eds., 2006).

${ }^{62} / d$. at 29.

${ }^{63}$ Shaffer, supra note 23 , at 243-44.
} 
If the ideas underpinning reflexive law are being adopted to tackle human trafficking - and slavery-like practices - in corporate global supply chains, then this approach to lawmaking needs to actually work. As stated by Dorf, "reflexive law is a mechanism by which collective decisions of society as a whole steer other actors and institutions." ${ }^{64}$ Reflexive law "is concerned with procedures for multi-participant law-making rather than with the resulting substantive norms." 65 Based on "social science systems theory and autopoiesis theory," reflexive law "refers to learning and exchange of demands, expectations and best practices between social sub-systems." 66 Autopoiesis theory originates from biology, covering "the basic principles of self-reproducing and self-organising systems." ${ }^{67}$ Reflexive law theory points out the "need for law to focus on regulation of self-regulation." 68 It needs, therefore, to be "tentative, experimental, and learning" 69 in developing its steering mechanisms, and evaluating their effectiveness, as "certain institutional frameworks facilitate reflexivity, while others discourage it." 70

Reflexive law requires constant self-critical review of social institutions and their processes. ${ }^{71}$ The legal framework is used to establish incentives and procedures which requires institutions to think critically, creatively, and continually about their internal process and methods of operating, with a view to establish their effect on external structures, individuals, and society at large. ${ }^{72}$ The complexity of how society-and sub-sets of society-operate precludes the legal framework from directly specifying how internal corporate procedures and processes are to be managed, merely stating that they have to be managed. While reflexive law, it is acknowledged, "cannot and should not replace command-and-control regulation in all domains," ${ }^{73}$ it is argued that modern society and-in

\footnotetext{
${ }^{64}$ Michael Dorf, The Domain of Reflexive Law, 103 COLUM. L. REV. 384, 398 (2003).

${ }^{65}$ Karin Buhmann, Reflexive Regulation of CSR to Promote Sustainability: Understanding EU Public-Private Regulation on CSR Through the Case of Human Rights, 8 INT'L \& COMP. CORP. L.J. 38, 55 (2010).

${ }^{66} / d$. at 16.

${ }^{67}$ RALF ROGOWSKI, REFLEXIVE LABOR LAW IN THE WORLD SOCIETY, 63 (2013).

${ }^{68} / d$. at 38.

${ }^{69}$ Peer Zumbansen, Law after the Welfare State: Formalism, Functionalism and the Ironic Turn of Reflexive Law, 56 AM. J. OF COMP. L. 769, 794 (2008).

${ }^{70}$ De Schutter \& Deakin, supra note 12 , at 4.

${ }^{71}$ Orts, supra note 13 , at 780.

${ }^{72}$ See id.

${ }^{73}$ Dorf, supra note 64 , at 398.
} 
the context of this paper-the businesses that operate in modern society are "so complex and fractured that command-and-control regulation is bound to fail." ${ }^{\prime 4}$

The reflexive law approach can be considered successful if it proves its capacity, in a particular context, "to engender responses of a certain kind within the relevant sub-systems." 75 In order to engender these responses, it may be necessary to use "combinations of 'hard' and 'soft' law in varying degrees." ${ }^{76}$ As pointed out by Deakin and McLaughlin, "a reflexive approach does not imply the absence of "hard law." 77 Rather, they say, "the legal framework has a number of roles to play: Inducing efficient disclosure, setting default rules and encouraging bargaining in the shadow of the law." ${ }^{18}$ These roles are set for reflexive law through the use of "both public and private law, official and unofficial" allied with "soft and hard norms." ${ }^{79}$ Default conditions need therefore to be set, which will "apply in the absence of agreement between social actors," 80 "legitimating the collective actors concerned," and "mandating disclosure of information needed for meaningful negotiation." ${ }^{81}$ The mechanisms, by which this legal framework will operate, need to be "identified, and once identified, must be affirmatively created." ${ }^{82}$ As pointed out by Deakin and McLaughlin, there is also a need for "bridging institutions" beyond the legal and enforcement framework "in which effective deliberation and participatory decision-making can occur." ${ }^{\prime 3}$ In the context of engagement with the corporate world, the "managerialization" of law is also key, whereby in-house corporate lawyers gain leverage over their internal governance structures, and can "use the threat of litigation, with the

\footnotetext{
${ }^{74}$ Id. at 395.

${ }^{75}$ Catherine Barnard et al., Reflexive Law, Corporate Social Responsibility and the Evolution of Labour Standards: The Case of Working Time 5 (ESRC Ctr. for Bus. Research, U. of Cambridge, Working Paper no. 294, 2004), https://www.cbr.cam.ac.uk/fileadmin/user_upload/centre-for-business-research/downloads/workingpapers/wp294.pdf.

${ }^{76} / d$. at 4 .

77 Simon Deakin \& Colm McLaughlin, Gender Inequality and Reflexive Law: The Potential for Different Regulatory Mechanisms for Making Employment Rights Effective 25, (ESRC Ctr. for Bus. Research, U. of Cambridge, Working Paper No. 426, 2011), https://www.cbr.cam.ac.uk/fileadmin/user_upload/centre-for-businessresearch/downloads/working-papers/wp426.pdf.

${ }^{78} / d$. at $21-22$

${ }^{79}$ Zumbansen, supra note 69, at 24.

${ }^{80}$ Deakin \& McLaughlin, supra note 77 , at 5.

${ }^{81} / d$.

${ }^{82} / d$.

${ }^{83} / d$. at 6 .
} 
potential for substantial liabilities and wider reputational losses, to persuade employers" to alter their course. ${ }^{84}$

\section{E. Trafficking as a Test Case of Reflexive Law}

Unlike the Californian Act-which focuses only on the supply chains for goods-the UK legislation covers both the supply of goods and services, ${ }^{85}$ and is to cover all sectors of these business operations. ${ }^{86}$ In addition, the UK Home Office envisages that it is to cover organizations carrying out any part of their business in the UK, with no minimum level of presence required in the jurisdiction for this legislative provision to apply. ${ }^{87}$

As referred to above, section 54 of the Modern Slavery Act 2015, ${ }^{88}$ takes the approach of making a business organization publish statements on its web site setting out the "steps the organisation has taken during the financial year to ensure that slavery and human trafficking is not taking place," "in any of its supply chains," and "in any part of its own business." 89 The assumption being taken is that such statements are reliable and rely on a properly conducted audit. If no such steps have been taken to ensure that slavery and human trafficking is not taking place within the business's global supply chain, then the organization must make a statement to that effect. ${ }^{90}$ If no such statement is made under Section 54 of the Modern Slavery Act, then the Secretary of State may bring "civil proceedings in the High Court for an injunction, or in Scotland, for specific performance of a statutory duty." ${ }^{91}$ Failure to comply with the injunction, or order of specific performance, would be contempt of court, and be "punishable by an unlimited fine." ${ }^{92}$ As stated by the Home Office, a statement to the effect that the undertaking has taken no such measures may damage the reputation of

\footnotetext{
${ }^{84} / d$.

${ }^{85}$ See Modern Slavery Act 2015, § 54(2).

${ }^{86}$ See Home OfFice, Modern SLAVery And Supply Chains Government Response Summary of Consultation Responses AND NEXT STEPS, 6 (2015) (Eng.).

${ }^{87}$ See id. at 6, para. 5(4).

${ }^{88}$ Now supplemented by the Modern Slavery act 2015 (Transparency in Supply Chains) Regulations 2015/1833, which came into force on October 29, 2015). See Modern Slavery Act 2015 (Transparency in Supply Chains) Regulations 2015, SI 2015/1833, § 2 (UK).

${ }^{89}$ Modern Slavery Act 2015, § 54(4).

${ }^{90}$ See id. at § 54(4)(b).

${ }^{91} / d$. at $\S 54(11)$.

${ }^{92}$ HOME OFFICE, supra note 35 , at 6.
} 
the business and should lead to pressure on the business from consumers, investors, and non-governmental organizations. ${ }^{93}$

The statements need to be signed by those responsible for the business-such as company boards and directors or a partner of the organization-so that "those at the top level take this issue seriously and understand the implications of taking little or no action." 94 Statements need to be published on the undertaking's website, with "a link to the slavery and human trafficking statement in a prominent place on that website's homepage." ${ }^{95}$ If the business has no website, alternative requirements have been set out in the act. ${ }^{96}$ In addition, there is an obligation on senior managers to "ensure everyone in the organisation is alive to the risks of modern slavery." ${ }^{\prime 7}$ The intention is to "create a race to the top by encouraging businesses to be transparent about what they are doing, thus increasing competition to drive up standards." ${ }^{\prime 98}$

Under the current UK legal framework, there is an assumption that consumers, investors, and non-governmental organizations have sufficient power, whether that be commercial, moral pressure, or under the legal framework, to be able to bring pressure to bear on the transnational corporations. ${ }^{99}$ This may be the case with regard to some, but not all relevant global supply chains.

The UK legal framework has addressed the disclosure aspects of laws modeled on the reflexive law approach, and there are hard law requirements compelling disclosure for companies with sufficient turnover. What is to happen once the necessary disclosure has been made, or the conditions required to be put in place in the lead up to the necessary disclosure, is, however, left unaddressed by the legal framework. The emphasis of the concepts underpinning reflexive law is to guide complexity. Standard setting in the public domain through traditional legislation is meant to have an effect on the private domain of internal corporate governance structures. This effect is then supposed to spill over into inter-business relations on the relevant market generally, and-in the context of this paper-through global supply chains. This is meant to occur through focusing business

\footnotetext{
${ }^{93}$ See id. at 6.

${ }^{94}$ Home Office, Modern Slavery and Supply Chains Consultation on the Transparency in Supply Chains Clause in the MODERN SLAVERY BILL 17 (2015).

${ }^{95}$ Modern Slavery Act 2015, § 54(7).

${ }^{96}$ See id. at § 54(8).

${ }^{97} \mathrm{HOME}$ OfFICE, supra note 35 , at 14.

${ }^{98} / d$. at 5 .

${ }^{99} / d$. at 6 .
} 
decision-making on meeting objectives already set by states and leaving to business to establish how best to attain those objectives in the context of their individual commercial activities. Disclosure requirements are meant to be merely one step in the process of orientating business through corporate governance structures to achieve those objectives. Default rules for disclosures, which are unsatisfactory or misleading, or even disclosures of negative information with regard to addressing modern slavery in global supply chains, in the absence of sufficient external pressure, have not been addressed by the UK legislation. There is an assumption by the UK legislators that consumers, investors, and non-governmental organizations ${ }^{100}$ will have sufficient power and resources to develop Deakin and McLaughlin's "bargaining in the shadow of the law." ${ }^{101}$ In order for the UK legislature to better reflect the concepts underpinning reflexive law, and in order to make its current Section 54 of the Modern Slavery Act 2015 provisions properly effective, further legal provisions are required.

Default conditions to be applied "in the absence of agreement between social actors,"102 and the relevant transnational corporations, are missing from the current UK legal framework. Criminal sanctions for non-engagement with these external stakeholders would also make this system more robust in light of the seriousness of the underlying crime of modern slavery. Also missing are bridging institutions beyond the legal and enforcement framework "in which effective deliberation and participatory decision-making can occur." 103

Flaws also arise in the context of the UK mandated information disclosure. As pointed out by Girard-writing in the context of substandard employment practices in global supply chains-not only is the issue that information is disclosed, but also "how the corporation discovers the reported information." ${ }^{104}$ Under the Californian Act there is a requirement, in Section 3, on corporations not only to "disclose audits of their supply chains," 105 but also to disclose whether those "audits were unannounced and performed by an independent party." ${ }^{106}$ In addition, the Californian law requires, at Section 3(c)(3), that direct supplies need to certify that materials incorporated into the product comply with slavery and human trafficking laws. This level of detail is currently missing from the provisions in Section 53 of the UK's Modern Slavery Act 2015. This issue is important, as, as pointed out by Narine, in

\footnotetext{
${ }^{100}$ See id.

${ }^{101}$ Deakin \& McLaughlin, supra note 77 , at 21-22.

${ }^{102} / d$. at 5.

${ }^{103}$ Id. at 6.

${ }^{104}$ Girard, supra note 3, at 332.

${ }^{105} / d$. at 337.

${ }^{106} / d$. at $337-38$.
} 
her paper on the U.S. Dodd-Frank Wall Street Reform and Consumer Protection Act 2010, in a survey on global supply chains, while 2,508 companies were surveyed, $28 \%$ had human rights policies, and $21 \%$ planned to implement them, only $6 \%$ claimed to actively monitor their global supply chains and only $7 \%$ had enforcement mechanisms. ${ }^{107}$ If all multi-national companies operate in essentially the same way, then similar issues will arise with the effectiveness of Section 53 of the UK's Modern Slavery Act 2015. The training requirements in section 53.5(f) of the UK laws or "its staff" appear to be broader than section 3(c)(5) of the California Act's requirements that company employees and management, who have direct responsibility for supply chain management, get the appropriate training.

The approach being taken in the UK's transparency in supply chains provisions are building on similar developments in the area of business ethics and human rights in a number of different forae, none of which, other than the above referred to Californian Act, specifically refer to human trafficking. For example, within the UK, companies are required under the Companies Act 2006 (Strategic Report and Directors' Report) Regulations $2013^{108}$ to report "to the extent necessary for an understanding of the development, performance or position of the company's business, include . . . information about . . . social, community and human rights issues ... including information about any policies of the company in relation to those matters and effectiveness of those policies." 109 Failure to properly prepare a strategic report leads to being guilty of an offense under which an individual can be criminally fined. ${ }^{110}$ The Home Office is of the view that for those companies obliged to provide both the Companies Act 2006 strategic report covering human rights-normally quoted companies-and to make the disclosure requirements under the Modern Slavery Act transparency in supply chains provisions, could prepare a statement that would meet with both requirements. As stated by the act, "it is envisioned most companies will opt for two separate statements." 111

While the Californian Act has been used above to identify and analyze weaknesses in the UK law on combatting human trafficking in global supply chains, substantial weaknesses remain in the US legal framework on this issue. The Californian Act does not have a direct counterpart at the US federal level, however, other, more limited, related provisions do operate. A US wide act, the Dodd-Frank Wall Street Reform and Consumer Protection Act 2010, at Section 1502, addresses the use of "any conflict minerals from the Democratic

\footnotetext{
107 See Marcia Narine, From Kansas to the Congo: Why Naming and Shaming Corporations Through the Dodd-Frank Act's Corporate Governance Disclosure Won't Solve Human Rights Crisis, 25 Regent U. L. REV. 351, 371 (2013).

${ }^{108}$ See Companies Act 2006 (Strategic Report and Directors' Report) Regulations 2013, SI 2013/1970 (Eng.).

${ }^{109}$ Id. at $\S 3$ (inserting a new $\S 414(C)(7)($ b)(iii) into the Companies Act 2006, c. 46 (Eng.)).

${ }^{110}$ See Companies Act 2006, c. 46, § 414(A) (Eng.).

${ }^{111}$ HOME OfFICE, supra note 35 , at 25.
} 
Republic of Congo (DRC) in their supply chains." 112 While limited in focus, Feasley argues that it has "been a model for other US regulatory efforts to eliminate forced labor from supply chains." 113 It has also been subject to criticism. For example, Narine points out that transnational corporations "often do not have as much leverage with their suppliers as one would think." 114 In addition, she argues that the drive to keep costs down and lax laws in a host country could undermine supply chain transparency rules. In addition, suppliers can always do business with less demanding transnational corporations, with a consequent change in suppliers being also very costly and time-consuming for the transnational corporation, and can adversely affect local employees, and by extension, the local economy. ${ }^{115}$

There is currently a proposed act before Congress, the Business Supply Chain Transparency on Trafficking and Slavery Act 2015-currently HR 3226-which is, at the time of writing, at the committee stage. Already in force at the federal level in the US is the 2012 Executive Order - Strengthening Protections Against Trafficking In Persons In Federal Contracts, or EO 13627. This Executive Order covers contracts "exceeding USD 500,000 that are performed abroad to develop robust risk assessment and compliance plans" to combat THB in their supply chain. ${ }^{116}$ While seen as being broad and ambitious, the order does not extend to non-US government procurement contracts. ${ }^{117}$ In addition, the US has in place the Alien Tort Statute, which some US writers see as being relevant in this area. The Alien Tort Statute (ATS) was initially enacted as part of the Judicature Act of 1789. While a long-standing piece of US legislation, it is only recently being pleaded in the context of human rights law. A recent case, Doe I et al. v. Nestle USA, ${ }^{118}$ before the Ninth Circuit did rule that slavery was "a universally prohibited customary international rights violation." ${ }^{119}$ Nevertheless, as Feasley points out, "no contested corporate ATS case has resulted in a jury verdict in favor of the human rights abuse victims in a US federal court." ${ }^{120}$ Concerns have been raised as to the levels of extraterritoriality being argued for in its application. Whether the US Alien Torts

\footnotetext{
${ }^{112}$ Ashley Feasley, Eliminating Corporate Exploitation: Examining Accountability Regimes as Means to Eradicate Forced Labor from Supply Chains, 2 J. OF HUM. TRAFFICKING 15, 24 (2016).

${ }^{113} / d$.

${ }^{114}$ Narine, supra note 107 , at 371.

${ }^{115}$ See id.

${ }^{116}$ Feasley, supra note 112 , at 25.

${ }^{117} / d$.

${ }^{118}$ See Doe I v. Nestle USA, Inc., 738 F. 3d 1048 (9th Cir. 2013).

${ }^{119}$ Feasley, supra note 112 , at 27.

${ }^{120} / d$. at 26.
} 
Statute will have any relevance to human trafficking in supply chain cases going forward has yet to be established.

While attempts by two jurisdictions - the UK and the early moving State of California-to address human trafficking and slavery in global supply chains have been addressed above to include the flaws and criticisms of their approach and perceived effectiveness to date, the EU has yet to make any attempts to legislate in this area. This is despite the fact that the EU was an early mover in legislating to combat human trafficking generally. The approaches modeled on reflexive law being taken by the UK and the State of California are not unknown to the EU, which has already adopted similar provisions in Directive 2014/95/EU. The EU should give some consideration to similarly legislating-perhaps using the concepts that underpin reflexive law-to combat human trafficking in global supply chains, while also benefiting from the experience and criticism of the earlier attempts to so legislate by the UK and the State of California.

Lessons can also be learned, by all jurisdictions, from other policy areas where the ideas underpinning reflexive law have informed legislative drafting. Reflexive law based regimes have been operating in a number of areas of transnational business in recent years, with an "analysis of the efficacy" of those regimes leading "to a conclusion that the most successful approach is a hybrid of all of the accountability regimes," ${ }^{121}$ requiring, in the context of business, "international regulation, market-based, civil-liability, and domestic regulation." 122 In addition, there would be a need for criminal liability provisions to be in place in the context of modern slavery, where appropriate, and the "bridging institutions" of Deakin and McLaughlin, where the "effective deliberation and participatory decision-making can occur," 123 in order to ensure that the objectives of the reflexive laws actually operate.

Commenting on the National Contact Points set up under the OECD Guidelines on Multinational Enterprises, Feasley stated that "as long as procedures ... are voluntary" then they "cannot function as the sole mechanism" to combat forced labor in supply chains. ${ }^{124}$ Gold, Tautrims, and Trodd state that "the traditional managerial paradigm of profit maximisation" requires ensuring that a company's global supply chain is slavery free in order to "trade-off against the risks of litigation and reputation damage." 125 This logic requires not just voluntary action to combat potential reputational damage, but also potentially high risks

\footnotetext{
${ }^{121}$ Id. at 16.

${ }^{122} / d$. at 15.

${ }^{123}$ Deakin \& McLaughlin, supra note 77 , at 6.

${ }^{124}$ Feasley, supra note 112 , at 23.

${ }^{125}$ Stefan Gold et al., Modern Slavery Challenges to Supply Chain Management, 20 SUPPly ChaIN MGMT.: AN INT'L J. 485,486 (2015).
} 
of litigation, whether that be criminal or civil. It would appear that regulation based on reflexive law by itself will not achieve its anticipated objectives. It needs to be backed up by traditional hard law. A reflexive law regulatory approach may, however, better negotiate complexity and extend the territorial reach of national and EU laws in ways that traditional hard laws cannot achieve by themselves. It is not clear that there are such high risks of litigation under the current UK legal framework. An effective "reflexive, negotiating government does keep (and does need) . . certain teeth and claws." ${ }^{126}$ Reliance on the market solely in order to achieve these objectives would be an error. As pointed out by Feasley, many believe that "corporate accountability for human rights" is a "disposable concept" when human rights promotion and corporate interests diverge. ${ }^{127}$

\section{G. Conclusion}

Globalization is clearly posing challenges for the regulation of both transnational and economic law, and for the need to address transnational criminality through transnational criminal law. Under traditional legal frameworks, the effectiveness of state command and control models stop at the border. ${ }^{128}$ There is a need to examine how states-in particular the larger and more economically active jurisdictions-can have an effect on the behavior of transnational business. Laws based on the approach of reflexive law are emerging as a possible additional tool for addressing these concerns. As stated above, the approach of "reflexive regulation" is to set the required objective by way of law-which is mandatory on the legal entities operating within a particular jurisdiction-but leaving to the market operators to "determine the most efficient and effective ways to achieve desired results." 129 Mechanisms based on reflexive law need to be properly designed and implemented in order to be effective.

The reflexive law approach has already been deployed in a number of areas of commercial activity by a number of jurisdictions. Assessments have already been made as to the effectiveness and weaknesses of reflexive law mechanisms in the commercial world. THB is one point at which the ostensibly legitimate commercial world bisects the transnational criminal world. Global anti-money laundering provisions and processes is a second. Measures have already been taken by a small number of jurisdictions to regulate for THB in global supply chains using reflexive law methodology. Similar measures could also be taken to tackle anti-money laundering. Weaknesses are already emerging in those reflexive law mechanisms adopted to tackle THB in global supply chains. In particular, the recently

\footnotetext{
126 Marius Aalders \& Ton Wilthagen, Moving Beyond Command-and-Control: Reflexivity in the Regulation of Occupational Safety and Health and the Environment, 19 L. \& PoL'Y 415, 436 (1997).

${ }^{127}$ Feasley, supra note 112 , at 18-19.

${ }^{128}$ Girard, supra note 3, at 322.

${ }^{129}$ Id. at 338 .
} 
enacted UK provisions, set out in section 54 of the Modern Slavery Act 2015, shows such weaknesses. In order to be effectively regulating by reflexive law provisions, which by its very nature is "tentative, experimental, and learning," ${ }^{130}$ the law needs to be subject to constant self-critical review of its institutions, and their processes, as to whether and how they are achieving the required steering mechanism. ${ }^{131}$ It also needs to be subjected to strong empirical testing before its effectiveness in any particular context can be truly established. ${ }^{132}$ There is already a need to revisit the UK provisions to tighten them up, in order to make them more effective, in lights of lessons learned elsewhere.

Some may argue that a weakness of all of the legal frameworks discussed above is that they are focused on larger multi-national companies. It is accepted by this writer that the burdens being imposed on companies by regulations based on reflexive law would be disproportionate if used against smaller companies, and smaller companies are "not likely to be regulated successfully by internal management systems," ${ }^{133}$ as smaller companies are typically more focused on survival. These smaller operations are best influenced through the larger multinational companies, and their horizontal provisions, developed by the larger companies for their particular context, and operating under transnational reflexive law regulation.

The use of transnational reflexive law-as opposed exclusive reliance on traditional, jurisdictionally based, command and control law-requires new, additional, ways of conceptualizing, designing, and assessing the effectiveness of law. For example, the "multi[i]-directional nature of transnational legal processes"134 would need to be acknowledged, together with their effect on "states that are strong and proximate to international institutions," or the relevant regulatory authority or jurisdiction. In addition the effect of these initiatives would have to be examined on those states "that are weak, distant, and peripheral." 135 Shaffer points out that not only does the law need to change, but so too does the perception of the relationship between the state and the market, and how the state operates this type of law. ${ }^{136}$ In addition, the role of governance structures

\footnotetext{
${ }^{130}$ Zumbansen, supra note 69, at 25.

${ }^{131}$ See Orts, supra note 13 , at 780.

${ }^{132}$ See Teubner, supra note 10 , at 276.

${ }^{133}$ Aalders \& Wilthagen, supra note 126 , at 432.

${ }^{134}$ Shaffer, supra note 23 , at 260.

${ }^{135} / d$.

${ }^{136}$ See id. at 259.
} 
within transnational corporations in achieving the objectives of the reflexive law and new accountability mechanisms needs to be developed. ${ }^{137}$

Reliance on reputation sensitivities-where these exists-market forces, and consumer pressure assumes that the public at large have access to relevant information, and can engage in "democratic control of enterprises' behaviour." 138 As Aalders and Wilthagen have pointed out, this requires "(1) systems monitoring, (2) intermediary structures and networks [echoed by Deakin and McLaughlin ${ }^{139}$ ], (3) corporate social responsibility, and (4) other market-oriented regulatory tools." ${ }^{140}$ A number of these are still missing from the UK legal framework on THB in global supply chains. An effective "reflexive, negotiating government does keep (and does need) ... certain teeth and claws." 141

The State of California has made a start in the US to tackling human trafficking and slavery in global supply chains. Other jurisdictions in the US need to catch up. Given the level of seriousness that the EU attributes to the issue of human trafficking, it should also consider legislating for human trafficking and slavery-like practices in global supply chains. Within Europe, both the UK and EU legal frameworks still require further development. The issues raised above will need to be considered in reviewing the effectiveness of these provisions based on reflexive law.

\footnotetext{
${ }^{137}$ See id.

${ }^{138}$ Aalders \& Wilthagen, supra note 126 , at 431.

${ }^{139}$ See Deakin \& McLaughlin, supra note 77 , at 6.

${ }^{140}$ Aalders \& Wilthagen, supra note 126 , at 431.

${ }^{141}$ /d. at 436.
} 